\title{
Evaluation of Regional Financial Management Training Programs in Human Resources Development Agency North Maluku
}

\author{
MUHAMMAD RIDHA ALBAAR ${ }^{1}$, ZULFIATI SYAHRIAL ${ }^{2}$, MARIA PARISTIOWATI ${ }^{3}$ \\ ${ }^{1}$ Department of Management Information, ACADEMY OF COMPUTER SCIENCE (AIKOM) TERNATE, INDONESIA, \\ E-mail: ridha_fara13@yahoo.co.id \\ ${ }^{2}$ Department of Educational Technology, JAKARTA STATE UNIVERSITY, INDONESIA, \\ E-mail: zulfiatisyahrial@gmail.com \\ ${ }^{3}$ Department of Chemistry Education, JAKARTA STATE UNIVERSITY, INDONESIA, \\ E-mail: maria.paristiowati@unj.ac.id
}

\begin{abstract}
The purpose of this study was to determine the effectiveness of the Regional Financial Management training program at the Human Resources Development Agency of North Maluku Province. This study is a program evaluation study that uses model four level Kirkpatrick's which includes the level of reaction, learning, behavior and results. In this study discussed the level of reaction at four levels. The reaction level is discussed about the training participants' reactions to the curriculum, education staff and training facilities. The curriculum components are discussed about training schedules, training materials, learning methods and media. In the education and training component, the reaction of the resource person and the training committee was discussed. The components of the education and training facilities are discussed about classrooms, dormitories, supporting facilities for training and consumption of education and training. The study used a mixed research approach (mixed methods), namely research that combines qualitative and quantitative approaches to answer research problems. Qualitative research is a process of scientific research to understand human problems in a social context by creating a comprehensive and complex picture presented, reporting detailed views of sources of information and carried out in natural settings without any intervention from the researcher. This study produces recommendations for reaction levels that can be used as references to improve the quality of the Regional Financial Management Training Program at the Human Resources Development Agency of North Maluku Province.
\end{abstract}

Keywords: Evaluation, Reaction Level, Kirkpatrick.

JEL Classification: A 


\section{Introduction}

State Civil Apparatus (ASN) has determine role in the successful implementation of national and regional development. ASN that can perform these roles are ASN has indicated competence of the attitudes and behavior of loyalty and obedience to the state, moral and good mentality, professional, aware of its responsibility as a public servant, and able to be the glue of national unity. Resource Development Agency of North Maluku (BPSDM) is one institution that serves conduct educational activities and training of the ASN at the Provincial Government of North Maluku.

Training or education and training is a learning process so that learners can develop their potential through the explanation and knowledge by using the theory and practice directly in the field. Evaluation of the training activity may include evaluation of learning outcomes and program evaluation.

Evaluation of learning outcomes in focus to assess the learning outcomes achieved by participants after attending a training program. While the program evaluation was conducted to assess the effectiveness and efficiency of the program. Program evaluation is more holistic than the evaluation of learning outcomes. By Gabriela and McAlpine (2016), the program is perceived by the participants and the identification of constraints, can be used for improvement of better program results (Gabriela \& McAlpine, 2016).

Training on Regional Financial Management is carried out in order to improve the ability of ASN. The level of achievement of training objectives largely unknown and has never been found a special report on the effectiveness of the program. Training Evaluation is the process of measurement, assessment and correction of input and outcomes of education and training. ASN education and training is an activity process to obtain ASN that is more qualified and has a good mental attitude, honest, disciplined and devoted behavior, so that it can improve service and protect the community as well as possible. research that explains financial management and evaluation is:

Research related to Regional Financial Management has been carried out by Roni (2016), this research departs from the desire to study and describe several matters related to transparent regional financial management in Tanah Datar District, first how transparent regional financial management, second what strategy is used to realize transparent financial management in increasing PAD. (Roni, 2016).

Research conducted by Jeane (2014), which focused on the organization of the training hall Training PIM IV Religious Manado using CIPP models used to evaluate a program that can measure the effectiveness of the various components of the achievement of goals and objectives Diklatpim IV. (Jeane, 2014). While the effectiveness of the training-related research has been carried out by Eva (2014) which is to investigate the effectiveness of training programs tiered basic level of teachers and early childhood, the study used a qualitative approach with case study method, the models used are The Four Level Kirkpatrick.

(Eva, 2014). Looking at the various problems that exist, it becomes the basis for the need for evaluation activities to see the effectiveness of the implementation of Diklat. But in reality, evaluation activities like this are rarely carried out by training institutes including the Human Resources Development Agency of North Maluku Province. The Human Resources Development Agency of North Maluku Province as the organizer of the education program in the North Maluku provincial government, needs to conduct an evaluation of its activities as a form of public accountability to the stake holders and plans to improve service delivery to users. In addition, it should be seen whether the training material provided is in accordance with the training participants' needs and how much the level of usefulness in the field is in providing regional financial management services to the community.

Basically the evaluation of this program is focused on the implementation of Regional Financial Management Training. This is because regional financial management training is a program implemented by the Human Resources Development Agency of North Maluku Province. The focus of the research that will be examined in this research is the reaction of the participants towards the 
Regional Financial Management training, which includes curriculum components, education staff and training facilities.

\section{Literature Review}

Evaluation is an activity that includes measurement and assessment. (Suharsini, 2012).

Scriven, as quoted by Davidson (2017), states that professional evaluation is defined as a systematic determination of quality or value of something. (Davidson, 2017).

The evaluation model developed by Kirkpatrick was known as "Kirkpatrick four levels evaluation model". The evaluation of the effectiveness of training programs according to Kirkpatrick includes four levels of evaluation, namely: level 1-reaction, leval 2- Learning, level 3- Behavior, level 4 - Result. (Kirkpatrick, 1998).

Sikula (2001), defines that training is a short-term educational process that uses systematic and organized procedures, while non-managerial workforce learns technical knowledge and skills for specific purposes (Sikula, 2001).

\section{Methodology/Materials}

The study aims to assess the evaluation more objective about the successes and constraints that result not maximal Financial Management Training program On the Human Resources Development Agency of North Maluku province. The method used in this evaluation study is descriptive quantitative method with in-depth qualitative deepening. Researchers as an evaluator using survey data, observations, interviews and document research together in the analysis by comparing, integrating, to compare the results of these data (Mertens, 2010).

The instrument used in this study are, questionnaire, interview, observation and document study. Quantitative data presented in the form of numbers, while the qualitative data in the form of words.In this study the respondents were 40 participants in regional education management training. The Kirkpatrick model focuses on the level of reaction.

\section{Results and Findings}

Evaluation is done to answer questions and apply indicators of success in determining the value or meaningfulness of something. Evaluation questions provide direction and basis for carrying out evaluations, without which evaluators will lose the expected focus. Therefore evaluation indicators are needed to determine the success characteristics of a program and are used as a tool to justify the success of a program. the evaluation results from the reaction level consist of curriculum, education staff and training facilities.

\subsection{Curriculum}

In the implementation of curriculum training it is very important that the curriculum is a guideline for learning and / training activities carried out to achieve certain capabilities, through the process of education (formal and non-formal education) that will not run without a curriculum. Reaction evaluation emphasizes the level of satisfaction during the training. To find out the respondent's reaction to the training curriculum, data was collected through questionnaires, the level of satisfaction was measured using a Likert scale consisting of 18 (eighteen) statement items for four sub-components consisting of: 1) training schedule of six items, 2) seven-point training material statement, 3) training method four-point statement, and 4) learning media the following two statements are the results of curriculum evaluation:

\subsubsection{Level of Satisfaction with Training Schedule}

Average rating of respondents based on the questionnaire results is 4.50 (very good), with a success rate of $90 \%$. This shows that respondents in regional financial management training are very satisfied, 
with the arrangement of learning schedules. Respondents argued that the time allocation of the training was in accordance with the material that must be learned in this training. And the average rating of respondents is based on the results of the 2.88 questionnaire (enough) with a success rate of $53 \%$, this shows that there are some time learning material too long so that respondents cannot capture all the material provided by the resource person (table 1), The statement was supported by research Azwar own learning schedule conformity with the submitted materials so that the training participants more disciplined in following good training (Azwar, 2019). In the training curriculum component related to the training schedule, the financial management training area for the learning process is 6 days with an average learning time of 8 study hours per day with 1 JP @ 45 minutes. Any method used by active learning is still time consuming because it is very important to strive so that no time is wasted. (Melvin, 2013).

Table 1. Results of Evaluation Training Schedule

\begin{tabular}{|c|c|c|c|}
\hline Statement & Average & $\%$ & Category \\
\hline The division of the learning schedule & 4,50 & 90 & Very good \\
\hline Allocation of time for each material & 3,75 & 75 & Good \\
\hline Time of Training and Implementation & 3,73 & 74,5 & Good \\
\hline Time learning some of the material is too long & 2,88 & 57,5 & Enough \\
\hline Schedule a break too short & 2,80 & 60 & Enough \\
\hline Too solid learning hours & 3,13 & 62,5 & Enough \\
\hline
\end{tabular}

\subsubsection{Level of Satisfaction with Training Materials}

The average assessment of training respondents is based on the results of the 4.38 questionnaire (very good), with a success rate of $87.5 \%$. This shows that education and training respondents were satisfied with the material presented in regional financial management training, most of the training material was very useful, namely related to the process of regional financial management starting from planning, budgeting, administration, accountability, and supervision (table 2). This statement is supported by Bagiyono's research, which states that the training material given to participants is very important so that it opens the participants' insight into receiving the material, the evaluation results discuss training material in a good category (Bagiyono, 2012), While Hania stated that the delivery and presentation of each participant training materials has been satisfactory and is in conformity with the objectives and requirements for trainees (Hania, 2015).

Table 2. Evaluation of Training Materials

\begin{tabular}{|c|c|c|c|}
\hline Statement & Average & $\%$ & Category \\
\hline The order of training material according to the stages of learning & 4,13 & 82,5 & Good \\
\hline Training material in accordance with the purpose of training & 4,38 & 87,5 & Verry Good \\
\hline Training material according to the needs of participants & 4,33 & 86,5 & Verry Good \\
\hline Training material is too shallow & 3,15 & 63 & Enough \\
\hline The learning method according to the characteristics of matter & 4,08 & 81,5 & Good \\
\hline Sebagian besar materi selalu melakukan visitasi internal & 3,73 & 74,5 & Good \\
\hline
\end{tabular}

\subsubsection{Level of Satisfaction of Learning Methods}

The average score of respondents based on the results of the 4.08 questionnaire (good) with a success rate of $81.5 \%$ (table3), this shows that the training respondents were satisfied with the components of the learning method delivered in the regional financial management training. this statement is supported by Riyan's research which states the material taught is the material listed in the curriculum (Riyan, 2017). Based on the results of previous research and research for the learning methods delivered by the speakers included in the category of both the speakers in providing material 
using learning methods for adults, as well as the ability of resource persons to activate the learning process in the classroom by motivating training respondents to improve competence in managing finance in the work unit

Table 3 Results of Evaluation of Learning Methods

\begin{tabular}{|c|c|c|c|}
\hline Statement & Average & $\%$ & Category \\
\hline Learning methods according to material characteristics & 4,08 & 81,5 & Good \\
\hline Learning methods facilitate understanding of the material & 4,00 & 80 & Good \\
\hline The learning method involves participation & 4,13 & 82,5 & Good \\
\hline Case surgical methods are always applied & 3,73 & 74,5 & Good \\
\hline
\end{tabular}

\subsubsection{Level of Satisfaction with Learning Media}

The average score of respondents based on the results of the 4.35 questionnaire (very good) with a success rate of $86.5 \%$ (table 4 ), this shows that the learning media used in financial training has met the media standards of the LAN. This statement is supported by research (Firman), the media used is very effective in training (Firman, 2013).

from the results of previous research and research stated that the media used in the training was included in the good category.

Table 4. Results of Learning Media Evaluation

\begin{tabular}{|c|c|c|c|}
\hline Statement & Average & $\%$ & Category \\
\hline Learning media support the delivery of material & 3,90 & 78 & Good \\
\hline Appropriate instructional media material characteristics & 4,35 & 86,5 & Verry Good \\
\hline
\end{tabular}

\subsection{The Training Workers}

Based on the observations of the teaching and learning staff used by resource sources, it was not systematic, this statement was supported by Jeane's research stating that the use of methods used by resource persons was less convincing for training participants, because it used a pedagogical approach, whereas the demands of informants were using andragogics (Jeane, 2014). This affects the readiness and quality of learning, there has not been a simultaneous dissemination of information on evaluating the performance of the sources provided by participants, this is important so that there will be improvements in the future mass or the next regional financial management training.

\subsection{Training Facility}

Furthermore, the responses or reactions of respondents to training facilities need to be considered intensively because they contribute directly or indirectly to the success of training programs, training facilities include classrooms, dormitories, supporting facilities, and consumption, the physical environment in the classroom can support or hinder active learning activities.

\subsubsection{Classroom}

The average score of the results of the respondents' training questionnaire on this item statement was 3.88 (good) with a success rate of $77.5 \%$ (table 5), this indicates that the training respondents were satisfied with the facilities in the classroom. This statement is supported by Riyan's research results that the learning space has met the standards, the feasibility of use, the conditions and the number of infrastructure facilities all support learning (Riyan, 2018). So it was concluded that the classrooms were in a good category because the regional financial management training was carried out in the hotel so that all the facilities provided were included in the good category 
Table 5. Classroom Evaluation Results

\begin{tabular}{|c|c|c|c|}
\hline Statement & Average & $\%$ & Category \\
\hline Setting the temperature in the room was appropriate & 3,75 & 75 & Good \\
\hline The seating arrangement is too close & 3,05 & 61 & Enough \\
\hline The seating arrangements of participants in the group & 4,13 & 82,5 & Good \\
\hline All the equipment needs are provided in class & 3,88 & 77,5 & Good \\
\hline Classroom cleanliness is maintained & 4,28 & 85,5 & Verry Good \\
\hline
\end{tabular}

\subsubsection{Boarding}

The average evaluation results for dormitories based on the results of the questionnaire were 3.65 with a success rate of $72.5 \%$ (table 6 ), where respondents gave very satisfactory answers to the dormitory facilities provided by the committee. this result was supported by Riyan's research, that the dormitory component in the form of representative rooms, bathrooms to sleeping equipment provided to training participants had met the criteria. Moreover, janitors who carry out their duties periodically are things that make participants in service in this aspect of the reaction (Riyan, 2018). Firman, the comfort of the hostel made the training participants feel calm in resting and in doing the assignments the participants did not feel disturbed so they could concentrate (Firman, 2013).

This shows that the boarding school dormitory facilities provide satisfaction to the training respondents, because the dormitory where the respondent stays is a hotel so that all dormitory facilities meet the boarding standards which are determined for a training center.

Table 6. Boarding Evaluation Results

\begin{tabular}{|c|c|c|c|}
\hline Statement & Average & $\%$ & Category \\
\hline Training rooms provide comfort & 3,63 & 72,5 & Good \\
\hline Cleanliness is well maintained hostel & 4,00 & 80 & Good \\
\hline The security of the hostel is well maintained & 3,95 & 79 & Good \\
\hline
\end{tabular}

\section{Conclusion}

1. There needs to be development and improvement of the training curriculum

- Modules or teaching materials must have learning objectives to be achieved in each learning process that will be carried out so that participants will be directed and can understand the material to be delivered by the speakers. Providing complete teaching modules that are in accordance with the syllabus and lesson plans (Training Plan).

- The material or learning material that is conveyed should have a balance that is flexibility and depth adjusted to the time available and the competencies that must be achieved.Improvements to the effectiveness of learning regional financial management training by the learning objectives.

- Learning methods used in education and training are not originally used but have been through selection according to instructional objectives. Where the role of good learning methods is very effective in achieving the expected learning goals.Organizers provide facilities and infrastructure by established standards.

- Learning process. Instructional media used in accordance with the systematic training learning objectives such as the use of books, transparency, audio-visual, internet, computers and others that can motivate interest in learning the training participants.

2. In the implementation of learning resource was instrumental then the speaker should understand matters related to learning that makes GBPP / SAP, assign learning activities teaching done, set a tool valuation to measure the success of learning, resource person must be creative in motivating and creating a classroom that is conducive to encouraging Sadae training 
participants so as to force himself to use verbal ability to ask and answer questions. Activeness in undergoing training participants in the learning process is one key to success pencapian learning objectives.

3. For the service of education and training for all committee awarded picket schedule so that they feel responsible in providing better services to the participants of the training.

4. Establish standardization of facilities and infrastructure in the area of financial management education and training conformed LAN Chief Regulatory Affairs. As well as increasing the comfort of the training participants should also be provided a means of worship, libraries are prepared and have the references required of participants, care of the local electricity (generator) should be conducted on a scheduled basis in order to remain in good shape to anticipate the disruption of PLN and the drop in voltage in the event simultaneously .

- Improvements to the effectiveness of learning regional financial management training by the learning objectives.

- Organizers provide maximum service to participants

- Organizers provide facilities and infrastructure by established standards.

- Providing complete training materials to support the learning process.

\section{Acknowledgements:}

This research work is supported by the North Moluccas Provincial Government

\section{References}

1. Arthur Riyan, Evaluation of Training Programs in Scientific Writing for Pusbangtendik Widyaswara Kemdikbud, Journal of Educational Research and Evaluation Vol 22, No 1, June 2018.

2. Basir Firman, Diklatpim IV Program Evaluation at Makassar Religious Education Training Center with Kirkpatrick's Model, Educational Evaluation Journal Vol 4, No. 2, 2013.

3. Bateman, Snell, Management, Leading \& Collaborating in a Competitive World, Tenth Edition. New York: McGraw-Hill Companies, Inc. 2013.

4. Dessler,Gary, Human Reseource Management, Eight Edition. New Jersey. Prentice Hall, Inc. Upper Sadie River, 2000.

5. Djaali and Pudji Muljono. Measurements in the Field of Education, Jakarta: Grasindo, 2008.

6. Gall, Meredith D., Gall, Joyce dan Brog, Walter R. Educational Research: An Introduction. New York: Pearson Education, 2007.

7. Gabriela dan Lynn McAlpine. (2016). "Helping teachers to focus on learning and reflect on their teaching what role does teaching contectx play?", Journal of Studies In Educational Evaluation, 48(2)

8. Hania Amina (2015), "Kirkpartick Evaluation Model in the Implementation of Training (Levels of Reaction and Learning) at the Perum Jakarta Education and Training Center", Indonesian Science Management Research Journal (JRMSI) Vol 6, No. 1,2015.

9. Iskandar Azwar, Kirkpatrick Model ASN Training Evaluation (Case Study of Effective Negotiation Skill Training at the Finance Center), Journal of Education Vol 20, No. 1, 2019

10.Jarvis, Peter. Adult Education and Lifelong Learning: Theory and Pratice, 3rd edition. London: Routledge Palmer,2004.

11.JodyL.Fitzpatrick, James R. Sanders, and Blaine R. Worthen, Program Evaluation: Alternative Approaches and Practical Guidelines.Boston: Pearson Education,2004.

12.John W. Creswell,Penelitian Kualitatif \& Desain Riset. Alih Bahasa: Ahmad Lintang.Yogyakarta:Pustaka Pelajar, 2014.

13.Miles, Mathew B., dan Huberman, A. Michael, Analisis Data Kualitatif, diterjemahkan oleh Tjetjep Rohendi Rohidi.Jakarta: UI-Press. 
14. Mochtar Kusuma, Educational Evaluation, Introduction, Competence and Implementation. Yogyakarta: Parama IImu, 2016.

15.Pallavi P. Kulkarni, A Literature Review on Training \& Development and Quality of Work Life, Journal of Arts, Science \& Comerce- International Refereed Reserch Journal, Vol IV(2), 2013.

16.Patricia L. Hardre, Janis Slater, dan Mark Nanny. (2010). "Redesigning and Aligning Assessment Journal Of Evaluation For a Federally Funded Math and scince Teacher Educational Program", Journal Of Evalution and Program Planing, 33 (4), 508.

17.Paivi Atjonen (2015). "Your career will be over, power and contradictions in the work of educational evaluators", Journal of Studies in Educational Evalution, 5.37.

18.Putera Ekha Roni Transparent Regional Financial Management in Tanah Datar District in Implementing Fiscal Decentralization, Sosiohumaniora, Vol. 18 (3), 2016.

19.Tulung Marie Jeane, "Evaluation of Level IV Leadership Education and Training Programs in Manado Religious Training Center", Acta Diurna Journal, Vol III (3), 2014.

20.R. Jone Gareth, and Jennifer M. Goerge, Conteporary Management, Third Edition. New York: McGraw-Hill/irwin, 2012.

21.Wirawan, Evaluasi: Teori, Model, Standar, Aplikasi dan Profesi (Jakarta: Rajawali Pres, 2012). 